Martirosyan E.I., POROShina V.D., Kupriy T.G. Historiography of development of higher education of U kraine in 1920 - 2007th : home history of political science aspect.

On the basis of the political history of political science and archived data of XX of item, in the article authors are analyse the historiography stages and periods of becoming and development of higher education in U kraine in 1920-2007.

Analysing the statutes of labour and professional school in the archived data 20-60 of XX of item, authors came to opinion, that Ukrainian scientific school passed a great creative and searching process, was a volume, professional, ideological on the certain historical periods of the development, but always distinguished and underlined historical and philosophical approach of scientific search in training of higher personnels of pedagogical and cultural direction.

$\mathrm{H}$ istoriography is a scientific search and researches of the protracted period of spiritual and educational life of U krainian society.

During the years of independence, during the period of assertion of sovereignty and democratic freedom, $U$ kraine needs to rethink its entire history, it requires analysis and rethinking of the centurieslong struggle for national statehood, taking into account past historical experience in solving new problems. Since 1991, the development of U kraine as an independent, legal, democratic state has become an impetus for the transition to a new state in the development of U krainian national historiography, for the creation of true history, facts and events of the U krainian nation.

U krainian historiography as a historical science and socio-political educational disciplines regains lost collectivity, human trust, world historiographic space, national-state idea, returns forgotten names and figures, restores dignity and self-confidence. Scientists and teachers of U kraine have embarked on a transformation of the worldview from authoritarianism to democracy, on building a civil society, restoring national thought and facts, and on restoring the U krainian state.

Keywords: scientific potential, professional school, training of higher personnels, educational life.

DOI: https://doi.org/10.31392/NZ-npu-142.2019.19

УДК 376-054.62:81'233:811.161.2

Московчук Н. М.

\title{
СТАН УКРАЇНОМОВНОї ПІДГОТОВКИ МАЙБУТНІХ ІНОЗЕМНИХ ФАХІВЦІВ ТЕХНІЧНИХ СПЕЦАЛЬНОСТЕЙ
}

У публікації подано аналіз стану україномовної підготовки майбутніх іноземних фахівців технічних спеціальностей, щуо навчаються у закладах вищої освіти Украйни. Представлено зміст науково-дослідної діяльності констатувального етапу експерименту, який був зосереджений на визначенні завдання констатувального етапу експерименту; формуванні груп студентів для проведення експериментального дослідження; розробиі критеріїв оиінювання рівнів сформованості украӥномовної професійно-комунікативної компетентності (лінгвістичний критерій, мотиваційний критерій, адаптаційний критерій, рефлексивно-оцінний критерій); відборі методів діагностування рівнів сформованості украӥномовної професійно-комунікативної компетентності; визначенні показників, що характеризують иі рівні; характеристиці рівнів сформованості україномовної професійно-комунікативної компетентності майбутніх іноземних фахівиів технічних спеціальностей (високий, задовільний, низький); проведенні діагностики рівнів сформованості украйномовної професійно-комунікативної компетентності майбутніх фахівців технічних спеціальностей та аналізі ї даних.

Здійснено аналіз поняття "критерій" та запропоновано власне його трактування. 
Для визначення рівнів сформованості україномовної професійно-комунікативної компетентності було розроблено методику для їх діагностики і проведено діагностувальний етап експерименту.

Вичення та аналіз наукової літератури, стану україномовної підготовки майбутніх іноземних фахівиів технічних спеціальностей та результатів констатувального експерименту підтвердили актуальність теми і зумовили необхідність розроблення й упровадження експериментальної моделі україномовної підготовки майбутніх іноземних фахівців технічних спеціальностей.

Ключові слова: критерій, украӥномовна підготовка, майбутні іноземні фахівиі.

Сучасні тенденції до універсалізації стандартів вищої освіти декларують необхідність і доцільність удосконалення якості освітніх послуг, що надаються іноземним студентам. Зважаючи на те, що в українських вишах серед іноземного контингенту особливою популярними, затребуваними $є$ технічні спеціальності, увагу зосереджено на україномовній підготовці майбутніх іноземних фахівців технічних спеціальностей, що покликана задовольнити освітні потреби іноземних громадян засобами української мови. Обрана тема зумовлює, зокрема, аналіз стану україномовної підготовки майбутніх іноземних фахівців технічних спеціальностей у закладах вищої освіти України.

Задля достовірної перевірки стану україномовної підготовки майбутніх іноземних фахівців технічних спеціальностей проведено констатувальний етап експерименту, що складавсь із двох частин: інформативно-аналітичної та діагностувальної.

Констатувальний етап експерименту проходив на базі Одеської національної академії зв'язку імені О.С. Попова, Одеського національного морського університету, Державного закладу “Південноукраїнський національний педагогічний університет імені К.Д.Ушинського”, Одеської державної академії будівництва та архітектури, Одеського національного політехнічного університету. В експерименті взяли участь 34 викладача української мови як іноземної, 42 викладача фрахових дисциплін, 120 майбутніх іноземних фахівців технічних спеціальностей IV курсів.

Зміст науково-дослідної діяльності констатувального етапу експерименту був зосереджений на визначенні груп студентів для проведення експериментального дослідження; розробці критеріїв оцінювання рівнів сорормованості україномовної професійно-комунікативної компетентності; відборі методів діагностування рівнів сорормованості україномовної профресійно-комунікативної компетентності; визначенні показників, що характеризують ці рівні; вивченні рівнів сформованості україномовної профресійно-комунікативної компетентності майбутніх іноземних фахівців технічних спеціальностей; аналізі даних діагностики рівнів сформованості україномовної професійно-комунікативної компетентності майбутніх фахівців технічних спеціальностей; аналізі даних оцінювання ставлення до процесу формування україномовної професійно-комунікативної компетентності майбутніх іноземних фахівців технічних спеціальностей під час профресійномовленнєвої підготовки студентів і викладачів української мови як іноземної та фахових дисциплін.

Завдання констатувального етапу експерименту: 1) вивчити стан україномовної підготовки майбутніх іноземних фахівців технічних спеціальностей; 2) визначити ставлення майбутніх іноземних фрахівців, викладачів української мови як іноземної та викладачів фахових дисциплін до 
україномовної підготовки майбутніх іноземних фрахівців технічних спеціальностей у процесі професійної підготовки у закладах вищої освіти; 3) визначити рівень сфрормованості україномовної професійно-комунікативної компетентності майбутніх іноземних фахівців технічних спеціальностей; 4) виявити типові труднощі, що виникають під час україномовної підготовки майбутніх іноземних фрахівців .

Інформативно-аналітичний експеримент проводивсь у формі спостереження за процесом україномовної підготовки майбутніх іноземних фахівців технічних спеціальностей, бесід та анкетування майбутніх іноземних фахівців, викладачів української мови як іноземної, викладачів фрахових дисциплін.

Завданням діагностувального етапу експерименту було визначення наявного рівня сорормованості україномовної професійно-комунікативної компетенції майбутніх іноземних фрахівців технічних спеціальностей на початок експериментальної роботи та аналіз типових помилок та труднощів, що виникають у процесі україномовної підготовки майбутніх іноземних фахівців технічних спеціальностей.

3 метою забезпечення ефрективного опрацювання результатів констатувального етапу експерименту було розроблено критерії оцінювання україномовної підготовки майбутніх іноземних фрахівців технічних спеціальностей. З'ясуємо насамперед значення поняття "критерій". Термінологічні джерела визначають "критерій” як: “сукупність ознак, на основі яких складається оцінка умов, процесу й результату освітньої діяльності, що відповідає поставленій меті, складають критерії і показники якості освітньої діяльності" [4, с. 434]; "підстава для оцінки, визначення або класифікації чогось; мірило" [12, с. 349]; "засіб міркування, ознака, на основі якої здійснюється визначення або класифікація чого-небудь, мірило оцінки" [8, с. 154].

За 3. Курлянд, розгляд будь-якої досліджуваної величини повинен включати в себе не тільки її ознаки, а й критерії, які визначають вираженість тієї чи тієї ознаки в розглядуваному процесі або явищі і $\epsilon$ мірилом оцінки, необхідною та достатньою умовою прояву або існування якогось явища чи процесу [6, 9]. Н. Баловсяк уважає, що критерії - це якості, властивості, ознаки об'єкта, що вивчається, які дають можливість дійти висновків про стан і рівень його сорормованості та розвитку [1]. Інші вчені (Т.Байраба, О. Савченко) розуміють критерій як реальні, точні обрані ознаки, величини, які виступають вимірниками об'єктів оцінювання $[9,5]$.

Зазначимо, що окремі вчені подають визначення понять "критерій" i “показник” у взаємозв'язку. Зокрема, А. Галімов зазначає, що критерій виражає найзагальнішу сутнісну ознаку, на основі якої здійснюють оцінку, порівняння реальних педагогічних явищ, при цьому ступінь вияву, якісна сорормованість, визначеність критерію виражаються у конкретних показниках [3, с.93]. А. Семенова вважає, що показники фріксують певний стан або рівень розвитку певного критерію. Показник, на думку дослідниці, це явище або подія, за якими можна судити про динаміку певного процесу [10]. Вчені (Ю. Туранов, В. Урський) уважають, що критерії - це мірило оцінювання вказаних параметрів, які описуються певними показниками [7].

Отже, критерій - об'єктивна ознака явища, що досліджується, за 
допомогою якої оцінюється ступінь сформованості цього явища. Ступінь сфрормованості того чи того критерію визначають за допомогою конкретних показників, що повно та об'єктивно характеризують критерій. Кожний критерій має певну кількість показників, які характеризують його у динаміці процесу формування цілісного явища, якістю якого $€$ цей критерій. Тож, наявність об’єктивних критеріїв сформованості україномовної професійно-комунікативної компетенції і їх показників дає змогу досягти об'єктивності оцінювання результатів україномовної підготовки майбутніх іноземних фрахівців технічних спеціальностей.

На основі загальноєвропейських рекомендації з мовної освіти, методик, розроблених А. Богуш [2], В. Краєвським [5], В. Сластьоніним [11], та відповідно до специфріки професійно-мовленнєвої компетенції майбутніх іноземних фрахівці було розроблено критерії оцінювання рівнів сорормованості україномовної профресійно-комунікативної компетенції майбутніх іноземних фрахівців технічних спеціальностей: лінгвістичний критерій (знання норм літературної мови, сорормованість механізмів сприймання та продукування мовлення у видах мовленнєвої діяльності професійного спрямування (діамонологічній діяльності (за А. Богуш), читанні, аудіюванні, письмі); мотиваційний критерій (усталений інтерес до україномовного професійного мовлення та потреба в україномовній професійно-мовленнєвій підготовці), адаптаційний критерій (орієнтування в україномовному соціумі, зокрема в галузі обраного фраху), рефлексивно-оцінний (об'єктивність і самокритичність в оцінці власних досягнень і досягнень інших майбутніх іноземних фахівців технічних спеціальностей) (див. таблицю 1).

Таблиця 1

Критерії оцінювання рівнів сформованості украӥномовної професійно-комунікативної компетенції майбутніх іноземних фахівців технічних спеціальностей і показники цих критеріїв

\begin{tabular}{|c|c|c|}
\hline № & Критерій & Показники \\
\hline 1 & Мотиваційний & $\begin{array}{l}\text { наявність потреби в україномовній } \\
\text { підготовці та в україномовній комунікації в } \\
\text { процесі професійної підготовки; } \\
\text { наявність позитивного ставлення і інтересу } \\
\text { до української мови як мови навчання. }\end{array}$ \\
\hline 2 & Адаптаційний & 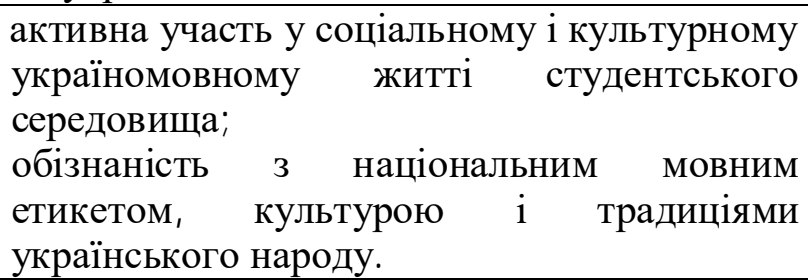 \\
\hline 3 & Лінгвістичний & $\begin{array}{l}\text { обізнаність } 3 \text { лексико-граматичними } \\
\text { нормами сучасної української літературної } \\
\text { мови; } \\
\text { наявність умінь аудіювання в межах } \\
\text { відповідного рівня володіння українською } \\
\text { мовою як іноземною; } \\
\text { наявність умінь україномовного писемного } \\
\text { мовлення в межах відповідного рівня }\end{array}$ \\
\hline
\end{tabular}




\begin{tabular}{|c|c|c|}
\hline № & Критерій & Показники \\
\hline & & $\begin{array}{l}\text { володіння українською мовою як } \\
\text { іноземною; } \\
\text { наявність україномовних діамонологічних } \\
\text { умінь і умінь читання україномовних } \\
\text { текстів. }\end{array}$ \\
\hline 4 & Рефлексивно-оцінний & $\begin{array}{l}\text { здатність до самодіагностики досягнень в } \\
\text { україномовній професійно-мовленнєвій } \\
\text { підготовці; } \\
\text { здатність оцінювати досягнення в } \\
\text { україномовній п професійно-мовленнєвій } \\
\text { підготовці майбутніх іноземних фахівців. }\end{array}$ \\
\hline
\end{tabular}

За визначеними критеріями та їх показниками було схарактеризовано рівні сформованості україномовної професійно-комунікативної компетентності майбутніх іноземних фахівців: високий, задовільний, низький. Запропоновані рівні відповідають етапу професійно-мовленнєвої підготовки учасників контрольних і експериментальних груп, а саме третьому та четвертому рокам навчання, коли має сформуватися ІІ середній рівень (B2) володіння українською мовою як іноземною. Під час діагностики навичок та вмінь у вживанні мовних засобів в основних видах професійно-мовленнєвої діяльності - читанні, письмі, діамонологічній діяльності й аудіюванні ми орієнтувалися на уніфіковану систему визначення рівня володіння українською мовою як іноземною - рекомендований Міністерством освіти і науки України (наказ Міністерства освіти і науки України від 24.06.2014 № 750) Стандарт 3 української мови як іноземної.

Схарактеризуємо якісний зміст рівнів. Високий рівень властивий майбутнім іноземним фахівцям, які обізнані з лексико-граматичними нормами сучасної української літературної мови відповідного рівня володіння українською мовою як іноземною; у них наявні уміння аудіювання в межах відповідного рівня володіння українською мовою як іноземною та уміння україномовного писемного мовлення в межах відповідного рівня володіння українською мовою як іноземною; вони володіють україномовними діамонологічними уміннями і вмінням читання україномовних текстів; мають високий рівень потреби в україномовній підготовці та в україномовній комунікації в процесі професійної підготовки; позитивно ставляться до української мови як мови навчання і виявляють інтерес до ії̈ вивчення; беруть активну участь у соціальному i культурному україномовному житті студентського середовища; добре обізнані з національним мовним етикетом, культурою і традиціями українського народу; здатні до адекватної самодіагностики досягнень в україномовній професійно-мовленнєвій підготовці; здатні дати адекватну оцінку досягнень в україномовній професійномовленнєвій підготовці інших майбутніх іноземних фрахівців.

Задовільний рівень властивий майбутнім іноземним фахівцям, які обізнані з лексико-граматичними нормами сучасної української літературної мови відповідного рівня володіння українською мовою як іноземною, водночас припускають незначні порушення цих норм; володіють умінням аудіювання в межах відповідного рівня володіння українською мовою як іноземною, однак у 
мовленні наявні окремі недоліки і огріхи; у них наявні вміння україномовного писемного мовлення в межах відповідного рівня володіння українською мовою як іноземною, проте трапляються поодинокі труднощі зі здійсненням компресії шляхом відкидання другорядної інформації та оформленням офіційно-ділової документації; у них сорормовані окремі україномовні діамонологічні вміннями та вмінням читання україномовних текстів, натомість наявні відхилення в логічності викладу та труднощі під час обґрунтування власних думок; мають ситуативну потребу в україномовній підготовці та в україномовній комунікації в процесі професійної підготовки; виявляють варіативне ставлення і нестійкий інтерес до української мови як мови навчання; періодично беруть участь у соціальному і культурному україномовному житті студентського середовища; частково обізнані з національним мовним етикетом, культурою і традиціями українського народу; їхні результати самодіагностики досягнень в україномовній професійно-мовленнєвій підготовці наближені до реальних; їхні результати оцінювання досягнень в україномовній професійно-мовленнєвій підготовці інших майбутніх іноземних фахівців наближені до реальних.

Низький рівень засвідчили майбутні іноземні фахівці, які поверхнево засвоїли лексико-граматичні норми сучасної української літературної мови відповідного рівня володіння українською мовою як іноземною; недостатньо оволоділи уміннями аудіювання в межах відповідного рівня володіння українською мовою як іноземною; вміння україномовного писемного мовлення не відповідають вимогам до рівня володіння українською мовою як іноземною B2; обсяг діамонологічних умінь і умінь читання україномовних текстів складає менше половини від норми відповідного рівня володіння українською мовою як іноземною, мають низький рівень потреби в україномовній підготовці та в україномовній комунікації в процесі професійної підготовки; байдуже або негативно ставляться до української мови як мови навчання і не мають до неї інтересу; зовсім або майже не беруть участь у соціальному і культурному україномовному житті студентського середовища; не обізнані з національним мовним етикетом, культурою і традиціями українського народу; їх результати самодіагностики досягнень в україномовній професійно-мовленнєвій підготовці не збігаються з реальними; їх результати оцінювання досягнень в україномовній професійно-мовленнєвій підготовці інших майбутніх іноземних фахівців не збігаються з реальними.

Для визначення рівнів сфрормованості україномовної професійнокомунікативної компетентності було розроблено методику для їх діагностики і проведено діагностувальний етап експерименту. Комплексний аналіз результатів діагностики рівнів сорормованості україномовної професійнокомунікативної компетентності майбутніх іноземних фрахівців технічних спеціальностей за лінгвістичним, мотиваційним, адаптаційним та рефлексивнооцінним критеріями дав змогу одержати такі дані: високим рівнем сорормованості україномовної професійно-комунікативної компетентності володіли 9,5\% майбутніх іноземних фрахівців технічних спеціальностей, задовільним - 25\%, низьким - 65,5\%. Ці результати подано в таблиці 2. 
Таблиця 2

Кїлькісний аналіз результатів діагностувального етапу експерименту

\begin{tabular}{|l|c|c|c|}
\hline \multirow{2}{*}{ Критерї } & \multicolumn{3}{|c|}{ Рівні сформованості украӥномовної професійно-комунікативної } \\
& \multicolumn{3}{|c|}{ компетентності } \\
\cline { 2 - 4 } & Високий \% & 3адовільний \% & Низький \% \\
\hline \hline Лінгвістичний & $9 \%$ & $23 \%$ & $68 \%$ \\
\hline Мотиваційний & $17,5 \%$ & $36 \%$ & $46,5 \%$ \\
\hline Адаптаційний & $3,5 \%$ & $20,5 \%$ & $76 \%$ \\
\hline Рефлексивно-оцінний & $8 \%$ & $20,5 \%$ & 71,5 \\
\hline Середній показник & $9,5 \%$ & $25 \%$ & $65,5 \%$ \\
\hline
\end{tabular}

Рівні сорормованості україномовної профресійно-комунікативної компетентності майбутніх іноземних фахівців технічних спеціальностей на констатувальному етапі дослідження подано на гістограмі (рис. 1).

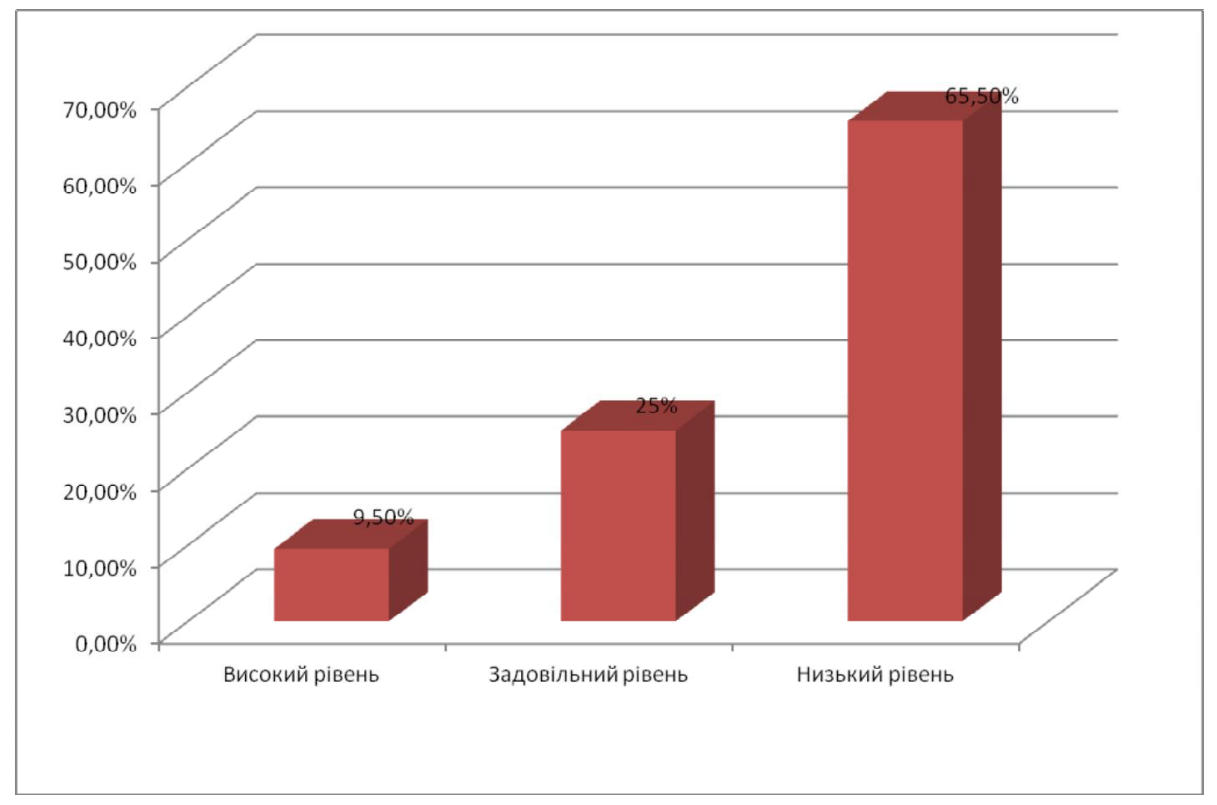

Рис. 1. Рівні сформованості україномовної професійно-комунікативної компетентності майбутніх іноземних фахівців технічних спеціальностей на констатувальному етапі дослідження

Аналіз наукової літератури, стану україномовної підготовки майбутніх іноземних фрахівців технічних спеціальностей та результатів констатувального експерименту підтвердили актуальність теми дисертації і зумовили необхідність розроблення й упровадження експериментальної моделі україномовної підготовки майбутніх іноземних фрахівців технічних спеціальностей.

\section{Використана література:}

1. Баловсяк Н. В. Формування інформаційної компетентності майбутнього економіста в процесі професійної підготовки : дис. ... канд. пед. наук : 13.00.04 / Інститут педагогіки і психології професійної освіти АПН України. - Київ, 2006. 334 с. 
2. Богуш А. М. Принципи модернізації вищої освіти. Психолого-педагогічні основи гуманізації навчально-виховного процессу школі та ВН3: зб. статей. Рівне, 2003. Вип. 4, Ч. 1. С.6-9.

3. Галімов А. В. Теоретико-методичні засади підготовки майбутніх офіцерів-прикордонників до виховної роботи з особовим складом: монографія. Хмельницький : Вид-во Нац. академії Державної прикордонної служби України ім. Б. Хмельницького, 2004. 376 с.

4. Енциклопедія освіти / Академія пед. наук України; головний редактор В. Г. Кремінь. Київ : Юрінком Інтер, 2008. 1040 с.

5. Краевский В. В. Методология педагогического исследования. Самара, 1994. 165 с.

6. Курлянд 3. Н. Професійна усталеність вчителя - основа його педагогічної майстерності. Одеса, 1995. $160 \mathrm{c}$.

7. Науково-дослідна робота в закладах освіти: методичний посібник / укл.: Ю. О. Туранов, В. І. Урський. Т. : АСТОН, 2001. - 140 c.

8. Професійна освіта : словник : навч. посіб. / уклад. С. Гончаренко [та. ін.] ; за ред. Н. Ничкало. Київ : Вища шк., 2000. - 380 с.

9. Савченко О. Я., Байраба Т. М. Об'єкти, функції і види контролю навчальних досягнень учнів початкових класів. Початкова школа. 2002. № 8. С. 4-7.

10. Семенова А. В. Парадигмальне моделювання у професійній підготовці майбутніх учителів : монографія / А. В. Семенова. Одеса : Юридична література, 2009. 504 с.

11. Сластенин В. А., Исаев И. Ф., Шиянов Е. Н. Педагогика : учеб. пособие для студ. высш. пед. учеб. заведений / под ред. В. А. Сластенина. Москва : Издательский центр "Академия", 2002. 576 с.

12. Словник української мови : [в 11 т.] / АН Української РСР, Ін-т мовознав. ім. О. О. Потебні ; редкол.: І. К. Білодід (голова) [та ін.]. Київ : Наук. думка, 1970-1980. - Т. 4 : І-М/ред. тому : А. А. Бурячок, П. П. Доценко. 1973. 840 С.

\section{References:}

[1] Balovsiak N . V . (2006). Formuvannia informatsiinoi kompetentnosti maibutnoho ekonomista v protsesi profesiinoi pidhotovky : dys ... kand. ped. nauk : 13.00.04 / Instytut pedahohiky i psykholohii profesiinoi osvity APN U krainy. - Kyiv, $334 \mathrm{~s}$.

[2] Bohush A.M. (2003). Pryntsypy modernizatsii vyshchoi osvity. Psykholoho-pedahohichni osnovy humanizatsii navchalno-vykhovnoho protsessu shkoli ta VNZ: zb. statei. Rivne, Vyp. 4, Ch. 1. S.6-9.

[3] Halimov A. V. (2004). Teoretyko-metodychni zasady pidhotovky maibutnikh ofitseriv-prykordonnykiv do vykhovnoi roboty z osobovym skladom : monohrafiia. Khmelnytskyi : $V$ yd-vo $N$ ats. akademii Derzhavnoi prykordonnoi sluzhby U krainy im. B. K hmel nytskoho, $376 \mathrm{~s}$.

[4] Entsyklopediia osvity / A kademiia ped. nauk Ukrainy; holovnyi redaktor V . H. K remin. K yiv : Y urinkom Inter, 2008. $1040 \mathrm{~s}$.

[5] K raevskij V. V. (1994). M etodologiya pedagogicheskogo issledovaniya. Samara, $165 \mathrm{~s}$.

[6] Kurliand Z. N. (1995). Profesiina ustal enist vchytelia - osnova yoho pedahohichnoi maisternosti. Odesa, $160 \mathrm{~s}$.

[7] Naukovo-doslidna robota $v$ zakladakh osvity: metodychnyi posibnyk / ukl.: Yu. O.Turanov, V. I. U rskyi. T. : A STON, 2001. - $140 \mathrm{~s}$.

[8] Profesiina osvita : slovnyk : navch. posib. / uklad. S. Honcharenko [ta. in.] ; za red. N. Nychkalo. Kyiv : Vyshcha shk., 2000. - $380 \mathrm{~s}$.

[9] Savchenko O.Y a., Bairaba T. M. (2002). Obiekty, funktsii i vydy kontroliu navchalnykh dosiahnen uchniv pochatkovykh klasiv. Pochatkova shkola. № 8. S. 4-7.

[10] Semenova A. V. (2009). Paradyhmalne modeliuvannia u profesiinii pidhotovtsi maibutnikh uchyteliv: monohrafiia / A. V. Semenova. Odesa : Y urydychna literatura. $504 \mathrm{~s}$.

[11] Slastenin V. A., Isaev I. F., Shiyanov E. N. (2002). Pedagogika : ucheb. posobie dlya stud. vyssh. ped. ucheb. zavedenij / pod red. V. A. Slastenina. M oskva : Izdatelskij centr "A kademiya", $576 \mathrm{~s}$.

[12] Slovnyk ukrainskoi movy : [v 11 t.] / AN U krainskoi RSR, In-t movoznav. im. 0. O. Potebni ; redkol.: I. K. Bilodid (holova) [ta in.]. Kyiv: Nauk. dumka, 1970-1980. - T.4 : I-M / red. tomu: A . A . Buriachok, P. P. Dotsenko. 1973. 840 C. 
Московчук Н. Н. Состояние украиноязычной подготовки будущих иностранных специалистов технических спеціальностей.

В публикации представлен анализ состояния украиноязычной подготовки будущих иностранных специалистов технических специальностей, обучающихся в учреждениях выстего образования Украины. Представлено содержание научно-исследовательской деятельности констатирующего этапа эксперимента, который был сосредоточен на определении задач констатирующего этапа эксперимента; формировании групп студентов для проведения экспериментального исследования; разработке критериев оченки уровней сформированности украиноязычной профессионально-коммуникативной компетентности (лингвистический критерий, мотивационный критерий, адаптационный критерий, рефлексивно-оценочный критерий); отборе методов диагностирования уровней сформированности украиноязычной профессионально-коммуникативной компетентности; определении показателей, характеризующих эти уровни; характеристике уровней сформированности украиноязычной профессионально-коммуникативной компетентности будущих иностранных специалистов технических специальностей (высокий, удовлетворительный, низкий); проведении диагностики уровней сформированности украиноязычной профессионально-коммуникативной компетентности будущих специалистов технических спеииальностей и анализе ее данных.

Осуществлен анализ понятия "критерий" и предложена собственная его трактовка.

Для определения уровней сформированности украиноязычной профессиональнокоммуникативной компетентности была разработана методика для их диагностики и проведен диагностический этап эксперимента. Изучение и анализ научной литературы, состояния украиноязычной подготовки будущих иностранных специалистов технических специальностей и результатов констатирующего эксперимента подтвердили актуальность темь и обусловили необходимость разработки и внедрения экспериментальной модели украиноязычной подготовки будущцих иностранных специалистов технических специиальностей.

Ключевые слова: критерий, украиноязычная подготовка, будущцие иностранные специиалисты.

MOSKOVChUK NATALIA. The developing communicative and ukranian environment as a leading factor of ukranian professional and communicative competence formation for future for eign specialists of technical specialties.

In the research the attention was focused on professional orientation of professional and speech training of future foreign specialists from technical specialties. Pedagogical conditions of Ukrainian professional and communicative competence formation of future foreign specialists from technical specialties are considered as circumstances which can affect efficiency of U krainian training of future foreign specialists and their personal qualities formation. Realization of such a pedagogical condition as ensuring the developing communicative and Ukrainian environment for foreign students of a technical profile is particularly extr emely urgent.

In the article the developing environment has been analysed according to the certain signs such as "speech", "communicative", "U krainian", "foreign". Different approaches to the definition of these concepts have been considered.

There are principles of the organization of the developing communicative and Ukrainian environment for foreign students of a technical profile which allow to provide the developing potential of a certain environment such as: a principle of communicativeness (it promotes successful achievement of a main goal for studying U krainian at the higher school - development of professional broadcasting of students in order to form the professional oriented language identity of a specialist according to modern requirements of the society and market conditions of work); a principle of situationality (it is directed to realize speech activities of students in professionally important situations); a principle of design activity (it promotes active independent activity of future specialists in realization of the imitated speech samples); a principle of advantage for communicative activities over activities of preparatory character (it points at the quality of knowledge and abilities which is required 
according to the educational program is implemented only in communications); a principle of unity of the complex and differentiated development of Ukrainian abilities (it shows close interrelation of lexicon, grammar, phonetics, spelling of U krainian and listening, a dialect, reading, writing in the specialty); a principle of a dominant role of exercises (it is implemented in educational process by students' performance of various exercises which induce students to implementation of the professional oriented speech activities with corresponding speech and intellectual operations); a principle of coincidence with texts (it provides cross-disciplinary relations between objects in the specialty of a student and a Ukrainian course which provides students' study with a support on professional materials and texts); a principle of visibility (it demands creating the corresponding conditions for sensory perception of the nearby environment and a professional environment which is not provided with real actions or professional conditions); a principle of scientific character (it appears from the link between the content of science and a subject); a principle of systemacity and sequence (it provides teaching a system of knowledge, skills in logical interrelation with a creative approach to study, the choice of the most rational system and the sequence of study according to a modular system taking into account a certain technical profession of future foreign specialists); a principle of stability of language knowledge, speech abilities and skills acquired in the course (it provides their reconstruction and application in future professional activity of the specialist); a principle of modularity (it demands distribution and structurization of a training material from the discipline "Ukrainian as a foreign language" ); a principle of individualization (it is based on the individual approach in study, considers the level of language training, individual and psychological abilities and qualities, individual solution of tasks, consultations and activization of intellection of each student); a principle of differentiation (it promotes creating conditions for all-round development of the language identity of students taking into account their inclinations, opportunities and interests); a principle of orientation to the future profession of students (it consists of mastering knowledge, skills which are professionally oriented on the future profession and a possibility of transformation with a gradual change according to requirements of the society to specialists of the corresponding professions); a principle of optimality (it allows to create conditions for realization didactic as well as specific principles from which the most favorable one is defined, the most appropriate in a concrete educational situation for achievement of the most effective educational result); a principle of the advancing study (it provides mastering scientific and cultural inheritance not only of all previous generations as well as formation of consciousness and outlook according to the latest requirements to specialists and requirements of the society and modern labor market); a principle "one person - one language" (A. Bogush) (it promotes the orientation in the environment of bilinguality and avoidance of dialects and "surzhyk" ); taking into account of the native language of foreigners (it provides comparison and differentiation of language units which prevents emergence of an interlingual interference and deviation).

Therefore, on the basis of scientific research it was made a conclusion that the efficiency of the developing communicative and Ukrainian environment is provided by its such characteristics: systemacity, stage-by-stage, systematicity, complexity, effectiveness, activity, focus, communicativeness, situationality, creativity, concreteness, multifunctionality, informational content, availability, associativity, adaptability, reflectivity, interactivity, flexibility, comfort, integrity, validity, orientation to the student's independence, dosed professional orientation, emotionality, validity, technologization.

Keywords: "speech environment", "communicative environment", "U krainian environment", "foreign environment". 